\title{
Technical and economical prefeasibility study of a solar water heating (SWH) system in an apartment building in Cape Town.
}

\author{
$1^{1^{*}}$ IDOWU Olugbeminiyi, ${ }^{2^{*}}$ IGE Toluwalope, ${ }^{3^{*}}$ LEGENSKI Nicole, ${ }^{4^{*}}$ MUSTAFA Amin A., ${ }^{5^{*}}$ ROJAS-SOLORZANO Luis \\ ${ }^{1,2,3,4}$ Ecole des Mines de Nantes, Department of Energy and Environment Systems \\ Nantes 44300, France \\ ${ }^{5}$ Nazarbayev University, Department of Mechanical Engineering \\ Astana, 010000, Kazakhstan \\ *E-mail: ${ }^{1}$ olugbeminiyi@gmail.com ${ }^{2}$ fetoige@yahoo.com ${ }^{3}$ nicole.legenski@gmail.com ${ }^{4}$ amin.moniem@gmail.com \\ 5luis.rojas@nu.edu.kz
}

Keywords: Solar Water Heaters (SWH), Cape Town, RETScreen, Prefeasibility, Glazed solar collectors, Unglazed solar colletors, Electricity saving

\begin{abstract}
Solar power has significant potential to reduce reliance on conventional energy sources in South Africa. A prefeasibility study for a communal solar water heating system (SWHS) is performed for an apartment building in the Cape Town area. Energetic-economic modelling of the system is performed via the calculation of the solar fraction, and fundamental indicators of the financial analysis such as internal rate of return (IRR), net present value (NPV), and benefit-cost ratio. Results indicate that a SWHS with a solar fraction of $32 \%$ and a benefit-cost ratio of 3.05 is realizable. Additionally, sensitivity analysis of financial results with respect to incentive rebate amount and electricity escalation rate is performed.
\end{abstract}

\section{Introduction}

The centrally generated electrical power in South Africa constitutes of $92.6 \%$ Coal-Fuelled Power - the aging coal-fuelled South African plants have the lowest operating efficiency in the world (de Groot, V.G, \& Sebitosi, 2013). Moreover, hot water heating represents up to $48 \%$ of total electricity consumption in South African homes (Geldenhuys, 1998). Although the country has a fairly high annual average solar irradiation levels of $5.4 \mathrm{kWh} / \mathrm{m}^{2} /$ day measured on a horizontal plane that could make solar energy recovery a favourable alternative (Boxwell, 2015), only about $1 \%$ of households utilize solar water heaters (DME, 2003). Rising electricity rates, capital investments in electricity production and distribution, as well as needs to reduce $\mathrm{CO}_{2}$ emissions have all led the government to start promoting alternative, renewable energy solutions to meet growing energy demands (Donev, van Stark, Blok, \& Dintchev, 2012).

Promoting solar water heating (SWH) has been at the forefront of this initiative, with significant grants being offered by Eskom, South Africa's public electricity utility. Between the years 2008 and 2011 alone, Eskom has incentivized 156,000 installations with its Solar Water Heating Rebate Programme and has partnered with the Department of Energy to reduce the demand on the public grid by 2,300 GWh through the use of SWH (ESKOM, 2012). The legislative capital of the country, Cape Town, has launched its own initiative in the form of the Residential Solar Water Heater Programme, which has encouraged residents through financial services and technical support to "invest to save" in SWH (City of Cape Town, 2011). With temperatures in Cape Town ranging from $2^{\circ} \mathrm{C}$ to $37^{\circ} \mathrm{C}$, an annual average of $17^{\circ} \mathrm{C}$ (The Weather Channel LLC, 2014) and an average of 2993 hours of sunshine per year (Climatemps, 2014), SWH is an attractive clean energy alternative to electric water heaters. According to a recent survey conducted by the City of Cape Town, nearly $70 \%$ of residents want a solar water heater (with energy cost savings cited as the primary reason), and half of the respondents replied that it is likely they would install one within the next three years (City of Cape Town \& Du Toit, 2013).

Given that energy cost savings are an important motivating factor for consumers who plan to install a solar water heating system (SWHS), economic feasibility studies of these types of systems could be useful decision-making tools. However, accurately predicting the long-term profitability of such investments are difficult due to the project's dependence on multiple external factors and thus require the use of a robust scientific model and careful precision of climatic and economic parameters to achieve an accurate result. Therefore, the purpose of this study is to perform a pre-feasibility study of a possible SWHS in the Cape Town area and to evaluate the sensitivity of various parameters to the long-term ability of the project to produce energy cost savings. In this study, the technical and economic prefeasibility of installing a collective domestic SWH system in an apartment building is evaluated using the RETScreen Clean Energy Project Analysis Software, an advanced model equipped to analyse feasibility and energy performance of clean energy projects. A pre-feasibility study of this nature is not currently available for South Africa in the literature, although there are similar types of feasibility studies 
for other locations throughout the world including Taiwan (Lin, Chang, \& K.M., 2015), Morocco (Allouhi, Jamil, Kousksou, El Rhafiki, Mourad, \& Zeraouli, 2015), Jordan (Kablam, 2004), Oman (Gastli \& Charabi, 2011), and Serbia (Stevanovic \& Pucar, 2012).

In this project, the RETScreen software is used to perform energy and economic feasibility analyses on a glazed flat-plate SWHS with electrical coil for auxiliary heating. The SWHS is designed for a new flat roof apartment building with 9 domicile units, located approximately $20 \mathrm{~km}$ southeast of the city centre and near the Cape Town International Airport. Hardware coefficients of performance are obtained for SWH units that are available for purchase in the Cape Town region, and pricing for these units and installations are provided by actual suppliers servicing the region.

The results of interest from this study include energy produced by the SWHS, energy costs avoided by using the SWHS, greenhouse gas (GHG) emissions avoided by using the SWHS, net present value (NPV) and internal rate of return (IRR) of the investment, as well as sensitivity of these results to parameters of the project such as changing electricity costs, loan interest rates, or government subsidy amount.

\section{Nomenclature}

\begin{tabular}{|c|c|}
\hline SWH & Solar Water Heating \\
\hline SWHS & Solar Water Heating System \\
\hline NPV & Net Present Value \\
\hline IRR & Rate of Return \\
\hline GHG & Greenhouse Gas \\
\hline$f$ & Solar Fraction \\
\hline$F_{R}(\tau \alpha)$ & Collector heat removal factor \\
\hline $\mathrm{F}_{\mathrm{R}} \mathrm{U}_{\mathrm{L}}$ & $\begin{array}{l}\text { Collector heat loss coefficient } \\
{[\mathrm{W} /(\mathrm{m} 2 \mathrm{~K})]}\end{array}$ \\
\hline $\mathrm{H}_{\mathrm{T}}$ & $\begin{array}{l}\text { Monthly average daily radiation } \\
\text { incident on the collector plane }\end{array}$ \\
\hline$T_{a}$ & Monthly average ambient temperature \\
\hline$T_{w}$ & Hot water temperature \\
\hline $\mathrm{T}_{\mathrm{m}}$ & $\begin{array}{l}\text { Monthly average water } \\
\text { temperature }\end{array}$ \\
\hline $\mathrm{C}_{\mathrm{a}}$ & Actual storage capacity \\
\hline $\mathrm{C}_{\mathrm{s}}$ & Standard storage capacity \\
\hline
\end{tabular}

\section{Literature Review}

The presence of similar feasibility studies for SWHS in the literature can be noted as early as 2002 , when Kablan (2004) performed a techno-economic analysis for an SWHS in Jordan. In this study, a model was developed to determine the economic feasibility of a SWHS with an electric coil as an auxiliary fuel as compared to the base case of a conventional gas-powered water heater. It was determined that the SWHS remained economically preferable if the auxiliary electric coil was used less than 120 days out of the year.

A study that is very similar in goal and scope to the current project was done by Gastli \& Charabi (2011), whom performed a full RETScreen analysis on a
SWHS in Oman. In this study, the SWHS was compared to the base case of a conventional electric-powered water heater. The project for a four-person household was assumed as financed $50 \%$ by government subsidies and $50 \%$ by the household. The pre-tax IRR for assets was calculated to be $12.2 \%$, and the equity payback period was found to be 8.5 years. In addition, the net annual GHG emission was reduced by $3.6 \mathrm{tCO}_{2}$ equivalents.

Another study based on RETScreen aimed to determine the financial feasibility of a SWHS in Serbia (Stevanovic \& Pucar, 2012). This study performed a RETScreen analysis in six Serbian cities for a SHWS for a household of 4 people. For a government subsidy of $50 \%$ of initial costs, equity payback period ranged from 4.7 to 6 years depending on the location. In addition, this study also made a financial analysis to determine the most appropriate level of government subsidies for the project.

\section{SWHS Prefeasibility Study in Cape Town}

\section{III.1. SWHS Design}

The purpose of this project is to determine the feasibility of a typical SHWS in the Cape Town area. Since South Africa's public utility ESKOM has implemented grants of $40 \%$ of initial costs, it is in the public interest to demonstrate that these types of projects can be profitable and to determine financial indicators such as equity payback period, IRR, and NPV. These results are here calculated using the support tool RETScreen, which comprises several types of analyses: energy model, GHG emission, reduction, cost, financial and risk analyses.

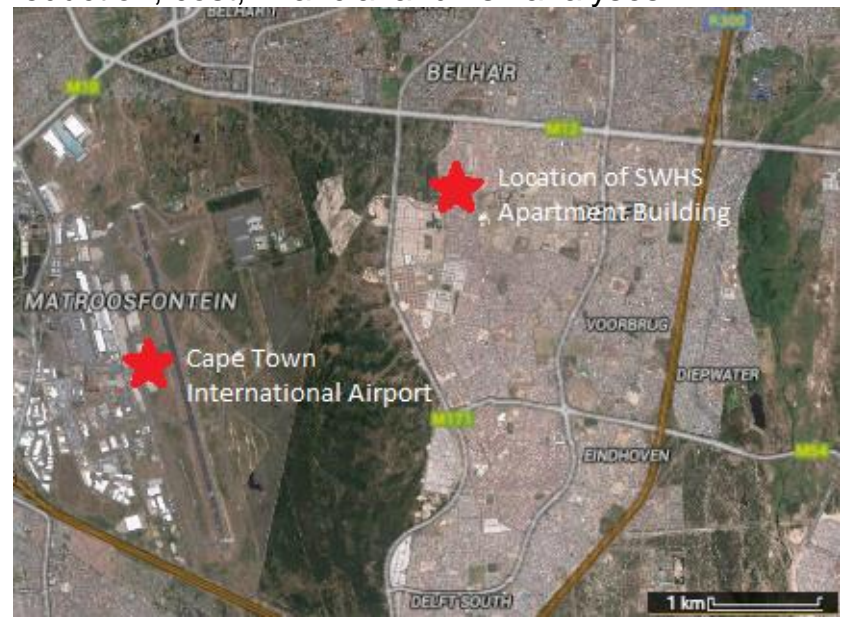

Fig. 1: Geographic location of SWH project (Google Earth, 2015).

In order to accomplish these objectives, it is necessary to design a SWHS with components that can be obtained in the region. For this project, a SWHS is conceived for the collective water heating of an apartment building. The area chosen for the placement of this system is near the Cape Town International Airport, as shown in Fig. 1. This location was chosen due to abundance of meteorological a solar irradiance data available for this area. Table 1, below, shows meteorological data for this area used by the model. 
Table 1: Meteorological data for Cape Town project area provided by RETScreen

\begin{tabular}{lcccc}
\hline Month & $\begin{array}{c}\text { Air } \\
\text { temperature }\end{array}$ & $\begin{array}{c}\text { Relative } \\
\text { humidity }\end{array}$ & $\begin{array}{c}\text { Daily solar } \\
\text { radiation }- \\
\text { horizontal } \\
\text { KWh/m} / \mathbf{d}\end{array}$ & $\begin{array}{c}\text { Heating } \\
\text { degree- } \\
\text { days }\end{array}$ \\
${ }^{\circ} \mathbf{C}-\mathbf{d}$ \\
\hline January & 20.4 & 68.0 & 7.72 & 0 \\
February & 20.4 & 69.9 & 7.05 & 0 \\
March & 19.2 & 72.6 & 5.86 & 0 \\
April & 16.9 & 76.6 & 4.17 & 33 \\
May & 14.4 & 79.6 & 2.97 & 112 \\
June & 12.5 & 79.9 & 2.45 & 165 \\
July & 11.9 & 78.9 & 2.62 & 189 \\
August & 12.4 & 78.6 & 3.40 & 174 \\
September & 13.7 & 76.6 & 4.75 & 129 \\
October & 15.6 & 71.6 & 6.09 & 74 \\
November & 17.9 & 68.9 & 7.48 & 3 \\
December & 19.5 & 68.4 & 7.85 & 0 \\
Annual & 16.2 & 74.2 & 5.19 & 879 \\
\hline
\end{tabular}

The apartment building is chosen to be a new flat-roofed structure with adequate space to accommodate the SWHS collectors and storage tanks. It comprises 20 glazed flat-plate solar panels, each with a gross area of $2.14 \mathrm{~m}^{2}$, a $150 \mathrm{~L}$ storage tank, and a thermosyphon passive heat exchanger from the Jiangsu Sunrain Solar Energy Company. A thermosyphon heat exchanger uses the natural circulation of warm and cool water to direct flow through the solar collector and to the hot water output of the unit. Figure 2 shows the general principle of such a unit. The apartment building has 9 domicile units, with four occupants each. It is assumed that each household member consumes an estimated $60 \mathrm{~L}$ of hot water per day (Donev, van Stark, Blok, \& Dintchev, 2012)

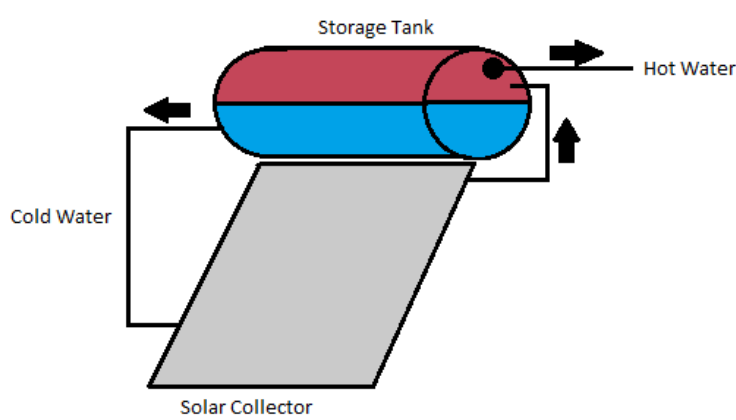

Fig. 2: Thermosyphon passive heat exchange, glazed flat-plate SWH

An important parameter in the feasibility of an SWHS project is the electricity rate. South Africa has historically had low electricity tariffs due to abundance of coal reserves, consistent government subsidies, and centralized control of both coal supply and electricity production (de Groot, V.G, \& Sebitosi, 2013). The electricity tariffs for domestic households of the city of Cape Town is indicated in Table 3.

\section{III.2. Energy Model}

The RETScreen energy model calculates the solar fraction $f$ in order to determine the amount of energy produced by the SWHS. The solar fraction refers to the amount of heating demand that is met by the SWHS. The solar fraction is calculated in the following manner (Stevanovic et al, 2012):

$$
f=1.029 Y \quad 0.065 X \quad 0.245 Y^{2}+0.0018 X^{2}+0.0215 Y^{3}
$$

Where $\mathrm{X}$ and $\mathrm{Y}$ are determined as follows:

$$
\begin{aligned}
& X=\frac{A_{C} F_{R} U_{L}\left(T_{\text {ref }} T_{a}\right)}{L} *\left(\frac{C_{a}}{C_{s}}\right) 0^{0.25} * \frac{\left(11.6+1.18 T_{w}+3.86 T_{m}\right.}{\left.2.32 T_{a}\right)} \\
& \left(T_{\text {ref }} T_{a}\right)
\end{aligned}
$$

Where $T_{\text {ref }}$ is $100^{\circ} \mathrm{C}, \mathrm{L}$ is the total monthly heating load, $\mathrm{C}_{\mathrm{a}}$ is actual storage capacity, $\mathrm{C}_{\mathrm{s}}$ is standard storage capacity, $N$ is the number of days in the month, $A_{c}$ is the collector area in $\mathrm{m}^{2}, \mathrm{~F}_{\mathrm{R}}(\mathrm{Ta})$ is the collector heat removal factor, $F_{R} U_{L}$ is the collector heat loss coefficient in $\mathrm{Wm}^{-2} \mathrm{~K}^{-1}, \mathrm{H}_{T}$ is the monthly average daily radiation incident on the collector plane, $\mathrm{T}_{\mathrm{a}}$ is the monthly average ambient temperature, $T_{w}$ is the hot water temperature, and $T_{m}$ is the monthly average water supply temperature.

Table 2 gives the necessary input parameters used for

\begin{tabular}{|c|c|c|}
\hline Parameter & Value & Unit \\
\hline Number of Units & 9 & \\
\hline Occupancy rate & 100 & $\%$ \\
\hline Daily Hot Water Use & 2160 & $\mathrm{~L} / \mathrm{d}$ \\
\hline Temperature of heated water & 60 & ${ }^{\circ} \mathrm{C}$ \\
\hline Operating days per week & 7 & \\
\hline Slope of collectors & 30 & degrees \\
\hline Aperture area per solar collector & 1,86 & $\mathrm{~m}^{2}$ \\
\hline Gross area per solar collector & 2,14 & $\mathrm{~m}^{2}$ \\
\hline $\operatorname{Fr}$ (tau alpha) coefficient & 0,67 & \\
\hline FrUL coefficient & 4,62 & $\mathrm{~W} / \mathrm{m}^{2} /{ }^{\circ} \mathrm{C}$ \\
\hline Number of Collectors & 20 & \\
\hline $\begin{array}{l}\text { Storage Capacity / solar collector } \\
\text { area }\end{array}$ & 70 & $\mathrm{~L} / \mathrm{m}^{2}$ \\
\hline Electricity rate & 0,11 & $€ / \mathrm{kWh}$ \\
\hline
\end{tabular}
this SWHS.

Table 2: Parameters used in Energy Model of SWHS

\section{III.3. Electricity Pricing}

In studying this feasibility for SWHS, electric heaters are considered as the base case with the cost of electricity being the fuel in comparison with the cost of solar radiation that is free. Electricity tariff in Cape Town is set by the City of Cape Town Electricity Services with different prices being set depending on the expected consumption of the residence (City of Cape Town, 2014). Table 3 shows the residential electricity pricing in place, however, the tariff used in modelling this case is that for a monthly consumption 
of $0-600 \mathrm{kWh}$ as set in July 2014. This is taking into account the consumption needs of the apartment model especially regarding hot water consumption of $240 \mathrm{~L} /$ day. Using a rate of $5.1 \mathrm{kWh} / 100 \mathrm{~L}$ to increase water temperature from $16^{\circ} \mathrm{C}$ to $60^{\circ} \mathrm{C}$ (Thomson, 2013), energy use for water heating could be up to 367 kWh/month. According to a survey by the (City of Cape Town \& Du Toit, 2013), electric water heater accounts for $30-50 \%$ of the domestic electricity bill of a household in Cape Town. Furthermore, this same survey presents that each household spends averagely R764.66 (537kWh) on electricity monthly.

Table 3: Residential Electricity Pricing in 2014/2015 (City of Cape Town, 2014)

\begin{tabular}{|c|c|c|c|}
\hline \multirow{2}{*}{\multicolumn{2}{|c|}{ Units Received (kWh / month) }} & \multicolumn{2}{|c|}{ Tariff (cents / kWh) } \\
\hline & & Rand & Euros \\
\hline \multicolumn{4}{|c|}{ Lifeline $(<450)$} \\
\hline \multicolumn{2}{|c|}{ First $50 \mathrm{kWh}$} & \multicolumn{2}{|c|}{ Free } \\
\hline Block 1 & $0-350$ & 96.12 & 7.1 \\
\hline Block 2 & $350-450$ & 233.30 & 17.3 \\
\hline \multicolumn{4}{|c|}{ Domestic (> 450) } \\
\hline Block 1 & $0-600$ & 153.63 & 11.4 \\
\hline Block 2 & $600+$ & 186.81 & 13.8 \\
\hline
\end{tabular}

According to the electricity services board of the city, the tariff is expected to increase by $9.92 \%$ in 2015 and $9.26 \%$ in 2016 (Rencontre, 2013). However, although future tariff changes is expected to occur in manner that cannot be readily modelled for the life time of the project, an escalation rate of $10.0 \%$ is factored in by assuming that the annual increase in electricity price during the lifetime of the project will remain at about the same rate for the 2015 and 2016 projections. Additionally, a trend analysis of the rate of price increase from 2006 to 2014 was made to define a cap of $15.34 \%$ whilst evaluating the sensitivity of the project to electricity price escalation.

\section{III.4. System Cost}

The selection of the system and its cost plays a fundamental role in the feasibility of the project. In defining the cost of the selected system, estimates were obtained from a Chinese supplier, two Eskom approved suppliers in Cape Town and an agent with the SWH division of Sustainable Energy Society of Southern Africa (SESSA). However, that presented by one of the suppliers in Cape Town was used as the supplier provided a breakdown of the individual components in the overall cost as detailed in Table 4. Furthermore the difference in the costs estimates from these four sources was little and a contingency of $10 \%$ is factored into calculations. Apart from the system cost, it was also important to factor in the installation and maintenance costs as well as the costs of auxiliary systems such as pipes and pumps.
Table 4: Cost Estimates for the selected SWHS

\begin{tabular}{lcc}
\hline \multicolumn{1}{c}{ Item } & \multicolumn{2}{c}{ Cost } \\
& Rand & Euros \\
\hline Feasibility Study & 8,605 & 559 \\
SWHS (x20) & 249,517 & 18,464 \\
Engineering and Installation & 146,356 & 10,830 \\
Training and Commissioning & 770 & 50 \\
Unskilled Labour & 847 & 55 \\
& & \\
Total & 406,096 & 29,958 \\
\hline 1 rand $=0.074$ euros & Prices inclusive of $14 \%$ VAT
\end{tabular}

\section{III.5. Financing}

As with most clean energy projects, the initial costs are often a barrier. According to a market research conducted by the City of Cape Town in 2013, $67.9 \%$ of respondents are desirous of SWHs, however, the SWH unit installation and upfront costs are given as the main hindrances to installing one. Duely noting that $67.2 \%$ of interviewed persons consider upfront cost as a major drawback (City of Cape Town \& Du Toit, 2013), in coping with this, Eskom offers a SWH rebate programme to cover initial costs. This rebate is about $40 \%$ of the cost of the solar collector unit and ranges from $€ 243$ to $€ 663$ (R3,280 to $R 8,964)$ for each unit installed that meets certain specified conditions. The calculation of the exact amount depends on the type of system installed (ESKOM, 2012). The system considered for this study meets the criteria for benefiting from the rebate and is estimated as $€ 7,640$ (€382 per unit).

However, considering that $54.2 \%$ of persons will be motivated to obtain a system only if there are no upfront costs and $62.5 \%$ would like to pay less than $€ 148$ $(R 2,000)$ for the initial cost of the system (City of Cape Town \& Du Toit, 2013), financial calculations of the viability of the project are made with the assumption that the remainder of costs not covered by the rebate is taken as a bank loan to be paid over a 5 year term. The complete financial parameters for the project are specified in Table 5.

Table 5: Financial Parameters for the Feasibility Study Simulation

\begin{tabular}{lcc}
\hline \multicolumn{1}{c}{ Financial Parameter } & Value & Unit \\
\hline Inflation Rate $^{1}$ & 5.3 & $\%$ \\
Fuel Escalation Rate $^{2}$ & 10.0 & $\%$ \\
Debt Ratio & 60.0 & $\%$ \\
Discount Rate & 9.0 & $\%$ \\
Debt Term & 5 & Years \\
Debt Interest Rate ${ }^{3}$ & 11.0 & $\%$ \\
System Life-time & 25 & Years \\
Government rebate for 20 units $^{4}$ & 7,640 & $€$ \\
\hline T(Triami Media BV, 2014$) ;{ }^{2}$ (Rencontre, & 2013); ${ }^{3}$ (Trading \\
Economics, 2014); ${ }^{4}$ (City of Cape Town, 2011) &
\end{tabular}




\section{Results and discussions}

Following the simulation of these design parameters as described in the preceding sections using RETScreen, the results obtained are as follows:

\section{IV.1. Energy Savings}

The designed SWHS provided 17MWh of heating per year, which is equivalent to a solar fraction of $42 \%$. The use of the system resulted in an electricity consumption of 23.3 MWh, compared to the base case consumption of $40.3 \mathrm{MWh}$. This represents an electricity savings of $17 \mathrm{MWh}$ per annum which is equivalent to $€ 1,934$.

\section{IV.2. Emissions Reduction}

The amount of emissions (normalised to tonnes of $\mathrm{CO}_{2}$ ) estimated from the use of the SWHS is $24 \mathrm{tCO}_{2}$ equivalents, while with the use of electricity for water heating, it was $41.5 \mathrm{tCO}_{2}$ equivalents. This results in a saving of $17.5 \mathrm{tCO}_{2}$ equivalents which is equivalent to 3.2 cars taken off the road in a year.

\section{IV.3. Financial Analysis}

The results obtained from the simulation of the financial parameters for an investment in the SWHS taking into consideration the present situation in South Africa and the projections described above in the Financial discussion section (and Table 5 above) show that the Net Present Value (NPV) on the investment is $€ 27,028$ with an Internal Rate of Return (IRR) of $17.3 \%$ and an equity payback time of 9.9 years. The benefits to cost ratio of the investment is 3.05 . Figure 3 below shows the progression of the cumulative cash flow from the investment over time.

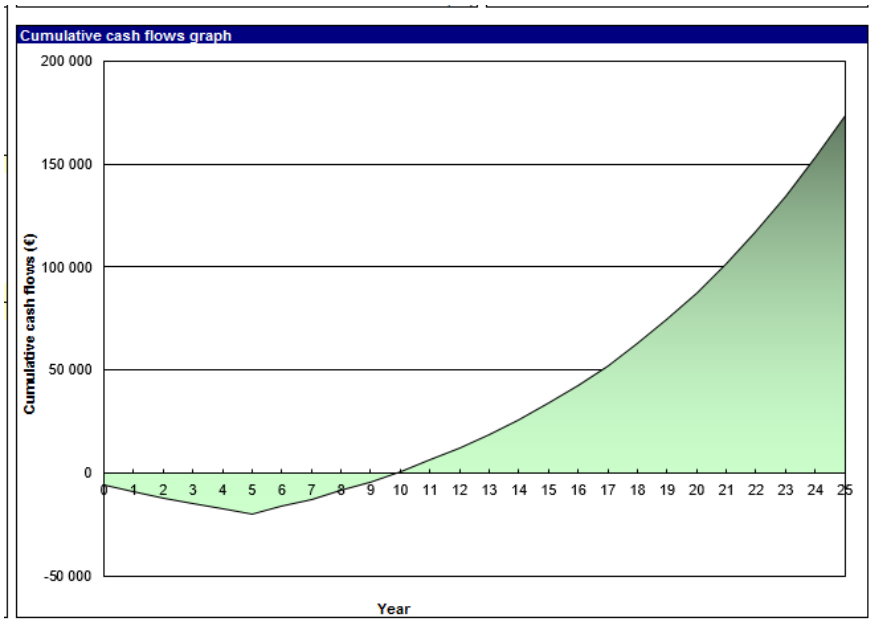

Fig. 3: RETScreen cumulative cash flow graph

With all the parameters employed for this simulation, it can be seen that the parameter with the highest influence on the profitability of this investment is the cost of the electricity, as seen from the relative impact graph shown in Fig. 4, based on a Montecarlo analysis of 500 combinations of possible scenarios with an uncertainty of $10 \%$.
Impact - After-tax IRR - equity

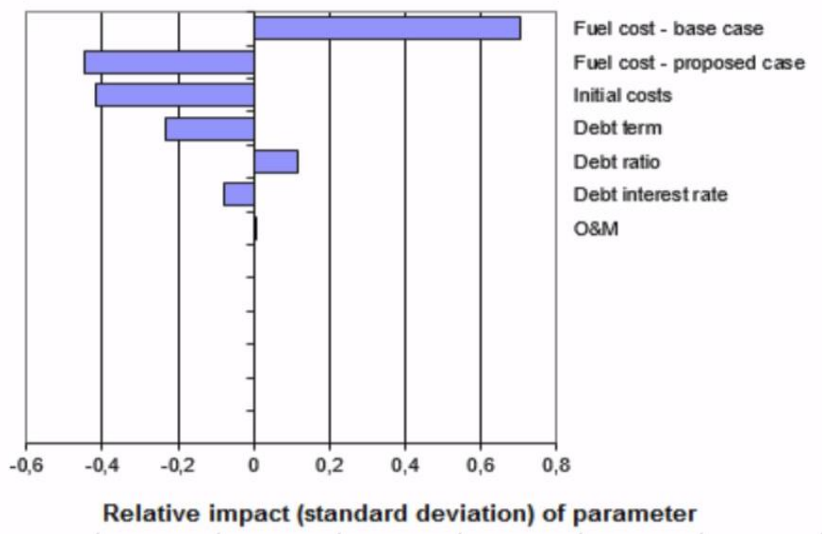

Fig. 4: RETScreen tornado diagram of sensitivity analysis on After-Tax IRR

From the relative impact shown in Fig. 4, it can be seen that the cost of fuel (which is the local cost of electricity) has a high impact on the viability of this project. This parameter was analysed by seeing how the variation of the escalation rate of electricity will affect the NPV, payback time and the IRR. Table 6 below shows how these values vary with the different escalation rate of electricity.

Table 6: Effects of changes in fuel escalation rates on financial returns

\begin{tabular}{ccccc}
$\begin{array}{c}\text { Fuel } \\
\text { Escalation } \\
\text { Rate }\end{array}$ & $\begin{array}{c}\text { After-Tax } \\
\text { IRR } \\
\text { Asset } \\
(\%)\end{array}$ & $\begin{array}{c}\text { Benefit } \\
\text { to } \\
\text { Cost } \\
\text { Ratio }\end{array}$ & $\begin{array}{c}\text { Equity } \\
\text { Payback } \\
\text { (years) }\end{array}$ & $\begin{array}{c}\text { NPV } \\
(\boldsymbol{(})\end{array}$ \\
\hline 5.0 & 10.5 & 1.25 & 12.3 & 3,294 \\
7.5 & 13.9 & 1.99 & 10.9 & 13,046 \\
10.0 & 17.3 & 3.05 & 9.9 & 27,028 \\
12.5 & 20.7 & 4.59 & 9.1 & 47,292 \\
15.0 & 24.2 & 6.85 & 8.4 & 76,909 \\
\hline
\end{tabular}

Another important parameter is the availability of rebate. Presently, the rebate is $40 \%$ of the cost of the equipment which amounts to $€ 7,386$. Figure 5 shows the effect of that a reduction or removal of this rebate will have on the After-tax IRR of the investment. The removal of the rebate will give an After tax IRR of $13.7 \%$, a payback period of 11.2 years, an NPV of $€ 19,642$ and a benefits-to-cost ratio of 2.49 .

\section{Conclusions}

With $42 \%$ in energy savings and a matching percentage in emissions reduction, it is very reasonable to say the justification behind the technical benefits of SWH have been validated in the case of an apartment building similar to the one defined in this work in the city of Cape Town, South Africa.

The designed SWHS yielded a yearly $17 \mathrm{MWh}$ in energy savings, $17.5 \quad \mathrm{tCO}_{2}$ equivalents emissions reduction along with a Net Present Value (NPV) on the investment of $€ 27,028$ with an Internal Rate of Return (IRR) of $17.3 \%$ and an equity payback period of 9.9 years. 


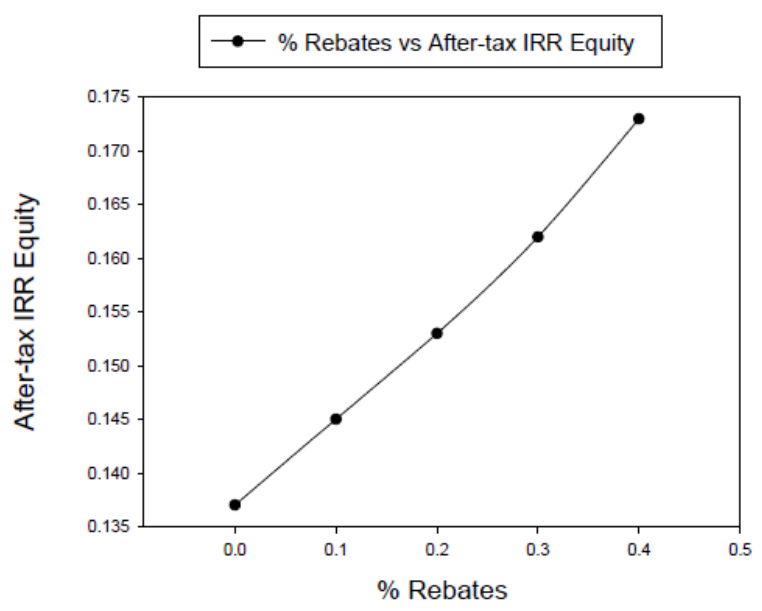

Fig. 5: After-tax IRR vs Rebates Sensitivity Analysis

Nevertheless, the current ESKOM rebate scheme plays a pivotal role in the attractiveness of investments in such SWH systems. The $40 \%$ rebate scheme (on initial investment) is responsible for a 1.3-year reduction of the payback period and a $5 \%$ reduction in the after tax IRR.

Although the rebate scheme was significant as $67 \%$ of the residents of Cape Town indicated concerns regarding the initial investment, the outcomes of the study highlight a greater financial sensitivity to the fuel escalation rate. Generally, the application and adoption of SWHS in Cape Town has yielded positive overall outcomes.

\section{Acknowledgements}

The team wishes to acknowledge and thank the Sustainable Energy Society of Southern Africa (SESSA), Prof. Bernard Bourges and Prof. Luiz Crespo for their contributions towards the successful finalization of this study. Additionally, the team would also like to extend its sincere appreciation to the EU's Education, Audiovisual and Culture Executive Agency (EACEA), specifically the Erasmus Mundus program for making the project possible.

\section{References}

Allouhi, A., Jamil, A., Kousksou, T., El Rhafiki, T., Mourad, Y., \& Zeraouli, Y. (2015). Solar domestic heating water systems in Morocco: An energy analysis. Energy Conversion and Management , 92, 105-113.

Boxwell, M. (2015). Solar Irradiance. Retrieved January 20, 2015 from Solar Electricity Handbook: http://solarelectricityhandbook.com/solar-irradiance.html City of Cape Town. (2014). Residential Electricity Tariffs Explanation.

City of Cape Town. (2011). Smart Living Handbook: Making sustainable living a reality in Cape Town homes. Cape Town. City of Cape Town. (2014). Solar Water Heaters: Why get a Solar Water Heater? Retrieved November 2014 10, 2014 from Saving Electricity: http://savingelectricity.org.za/pages/water_heaters.php City of Cape Town, \& Du Toit, J. (2013). Final Report: Market Research - Prospective Solar Water Heater / Heat Pump Market in the Cape Town Metropole. Cape Town: Sheryl Ozinsky Consulting.
Climatemps. (2014). Cape Town Climate and Temperature. Retrieved November 10, 2014 from Climatemps: http://www.cape-town.climatemps.com/

de Groot, R., V.G, v. d., \& Sebitosi, A. (2013). Comparing solar PV (photovoltaic) with coal-fired electricity production in the centralized network of South Africa. Energy , 55, 823-837.

DME. (2003). White Paper for the Promotion of Renewable Energies and Clean Development. Pretoria: Department of Minerals and Energy.

Donev, G., van Stark, W., Blok, K., \& Dintchev, O. (2012). Solar water heating potential in South Africa in dynamic energy market conditions. Renewable and Sustainable Energy Reviews , 16, 3002-3013.

ESKOM. (2012). COP17 fact sheet: Solar Water Heating Rebate Programme. Retrieved November 10, 2014 from http://www.eskom.co.za/AboutElectricity/FactsFigures/Docu ments/The_Solar_Water_Heating_SWH_Programme.pdf

Gastli, A., \& Charabi, Y. (2011). Solar water heating initiative in Oman energy saving and carbon credits. Renewable and Sustainable Energy Reviews , 15, 1851-1856.

Geldenhuys, A. (1998). ESKOM Domestic Load Research. Google Earth. (2015). Retrieved 2015 from Google Earth: earth.google.com

Kablam, M. (2004). Techno-economic analysis of the Jordanian solar water heating system. Energy, 29, 1069-1079.

Lin, W., Chang, K., \& K.M., C. (2015). Payback period for residential solar water heaters in Taiwan. Renewable and Sustainable Energy Reviews , 41, 901-906.

Maps, G. (2015).

Rencontre, L. (2013, May). Presentation to NERSA. City of Cape Town Electricity Services . Cape Town: City of Cape Town.

Stevanovic, S., \& Pucar, M. (2012). Financial measure Serbia should offer for solar water heating systems. Energy and Buildings , 54, 519-526.

The Weather Channel LLC. (2014). Weather History for Cape Town, South Africa. Retrieved November 10, 2014 from Weather http://www.wunderground.com/history/airport/FACT

Thomson, R. (2013, February 14). Measuring residential electricity savings in South Africa after solar or heat pump installations - a simple, reliable method. Retrieved January 10, 2015 from Environment News South Africa: http://www.environment.co.za/environmental-issues-news/m easuring-residential-electricity-savings-in-south-africa-aftersolar-or-heat-pump-installations-a-simple-reliable-method.ht $\mathrm{ml}$

Trading Economics. (2014). South Africa Prime Overdraft Rate. Retrieved 2014 йил November from Trading Economics:

http://www.tradingeconomics.com/south-africa/bank-lending -rate

Triami Media BV. (2014 йил November). Historic Inflation South Africa - CPI Inflation. From Worldwide Inflation Data: http://inflation.eu/ 